\title{
Kompetensi Pedagogik Dan Profesional Guru Fisika Dalam Melaksanakan Pendekatan Saintifik Di SMAN Sleman
}

\author{
Ratna Wahyu Wulandari ${ }^{1}$, Mundilarto ${ }^{2}$ \\ ${ }^{1}$ Program Studi Pendidikan Sains, Program Pascasarjana, Universitas Negeri Yogyakarta \\ ${ }^{2}$ Program Studi Pendidikan Fisika, FMIPA, Univesitas Negeri Yogyakarta \\ Email: ${ }^{1}$ Ratnawahyuwulandari2014@gmail.com, ${ }^{2}$ mundilarto@uny.ac.id
}

\begin{abstract}
Abstrak
Tujuan penelitian ini adalah untuk mendeskripsikan: (1) kompetensi pedagogik guru fisika dalam melaksanakan pendekatan saintifik di SMA Negeri di Kabupaten Sleman DIY; (2) kompetensi profesional guru fisika dalam melaksanakan pendekatan saintifik di SMA Negeri di Kabupaten Sleman DIY; (3) korelasi antara kepemimpinan kepala sekolah dengan kompetensi pedagogik dan profesional guru fisika dalam melaksanakan pendekatan saintifik; dan (4) korelasi antara pelatihan guru dengan kompetensi pedagogik dan profesional guru fisika dalam melaksanakan pendekatan saintifik. Penelitian ini merupakan penelitian survei. Objek penelitian ini adalah kompetensi pedagogik dan profesional guru fisika. Penelitian ini menghasilkan: (1) kompetensi pedagogik guru fisika dalam melaksanakan pendekatan saintifik secara keseluruhan dikategorikan baik berdasarkan hasil yang diperoleh dari triangulasi data dari instrumen angket, observasi, dan wawancara.; (2) kompetensi profesional guru fisika dalam melaksanakan pendekatan saintifik secara keseluruhan dikategorikan baik berdasarkan hasil yang diperoleh dari triangulasi data dari instrumen angket, observasi, dan wawancara; (3) korelasi kepemimpinan kepala sekolah dengan kompetensi pedagogik guru fisika dalam melaksanakan pendekatan saintifik dikategorikan sangat lemah, dan dengan kompetensi profesional guru fisika dalam melaksanakan pendekatan saintifik dikategorikan kuat; dan (4) tidak ada korelasi yang signifikan antara pelatihan guru dengan kompetensi pedagogik dan profesional dalam melaksanakan pendekatan saintifik guru fisika.
\end{abstract}

Kata Kunci: kompetensi pedagogik, kompetensi profesional, pendekatan saintifik

\section{Pendahuluan}

Kompetensi seorang guru yang profesional memilki kaitan erat dengan rumusan dari Undang-Undang Nomor 14 Tahun 2005 Pasal 1 ayat 4 . Rumusan tersebut menjelaskan tentang ukuran penting yang menjadikan guru dianggap sebagai sebuah profesi, yaitu (1) menjadi sumber penghasilan kehidupan; (2) memerlukan keahlian; (3) memerlukan kemahiran; (4) memerlukan kecakapan; (5) adanya standar mutu atau norma tertentu; dan (6) memerlukan pendidikan profesi. Kualitas profesi seseorang disebut sebagai profesionalisme. Profesionalisme tersebut merupakan kecenderungan sikap, mental atau tindakan dalam menjalankan profesinya. Hal ini berkaitan juga dengan komitmen seseorang untuk menjalankan tugas dan fungsinya.

Peran dan fungsi guru tidak bisa dipisahkan dari fungsi guru sebagai bagian dari perubahan sosial di masyarakat. Masyarakat beranggapan bahwa guru dapat memenuhi kebutuhan masyarakat di bidang pendidikan. Ada pandangan bahwa perilaku guru merupakan bentuk nyata dari profesionalisme. Guru profesional dianggap sebagai guru yang fokus pada usaha pengajaran dan pendidikan. Guru profesional dalam hal ini adalah guru yang tidak terlibat dalam kegiatan politik, sekalipun masalah politik pendidikan atau pendidikan politik.

Posisi sosial guru di masyarakat akan berkembang seiring dengan perkembangan zaman yang ada di sekitar kita yang berkaitan dengan kebutuhan masyarakat. Kebutuhan terhadap lembaga pendidikan membuat masyarakat mempertanyakan kembali mengenai status sosial guru dan makna guru bagi masyarakat. Guru kadang mendapatkan sanjungan sebagai "pahlawan tanpa tanda jasa", tetapi di sisi lain tenaga pendidik ini juga mendapatkan berbagai kritikan yang berkaitan dengan mutu pendidikan di Indonesia. Kondisi tersebut disadari oleh pemerintah, sehingga 
pemerintah melalui Kementrian Pendidikan dan Kebudayaan terus melakukan upaya perbaikan peraturan dan pelayanan pendidikan. Salah satu diantaranya adalah mengeluarkan UndangUndang Sistem Pendidikan Nasional dan Undang-Undang Guru dan Dosen untuk memperbaiki sistem dan pelayanan pendidikan.

Standar Nasional Pendidikan (SNP) pasal 28 menyatakan bahwa guru sebagai pendidik harus memiliki kualifikasi akademik dan kompetensi sebagai agen pembelajaran, sehat jasmani dan rohani, serta memiliki kemampuan untuk mewujudkan tujuan pendidikan nasional. Saat ini, peranan seorang guru sudah memasuki era baru. Guru dituntut untuk lebih profesional. Salah satunya adalah dengan diberlakukannya sistem portofolio dan sertifikasi. Setiap guru dituntut untuk tidak hanya mengajar tetapi juga terus-menerus meningkatkan kapasitasnya baik dari sisi keilmuan maupun dari sisi profesionalitas. Hal ini dilakukan karena dengan pesatnya perkembangan teknologi, tanpa didukung ilmu-ilmu baru dan teknik pembelajaran yang lebih aplikatif, fungsi guru akan termarjinalisasi di tengah pesatnya arus informasi.

Undang-Undang Nomor 14 Tahun 2005 tentang Guru dan Dosen Pasal 2 menjelaskan bahwa guru mempunyai kedudukan sebagai tenaga profesional pada jenjang pendidikan dasar, pendidikan menengah, dan pendidikan anak usia dini pada jalur pendidikan formal yang diangkat sesuai dengan peraturan perundang-undangan. Guru adalah pendidik profesional dengan tugas utama mendidik, mengajar, membimbing, mengarahkan, melatih, menilai, dan mengevaluasi peserta didik pada pendidikan anak usia dini jalur pendidikan formal, pendidikan dasar, dan pendidikan menengah. Hal ini dijadikan sebagai acuan oleh pemerintah untuk membuat standar kompetensi guru untuk memperoleh tenaga pendidik yang berkualitas.

Mulyasa (2013, p.17) berpendapat bahwa standar kompetensi guru dibuat untuk mendapatkan guru yang baik dan profesional, yang memiliki kompetensi untuk melaksanakan fungsi dan tujuan sekolah khususnya, serta tujuan pendidikan pada umumnya, sesuai kebutuhan masyarakat dan tuntutan zaman. Kompetensi guru memberikan manfaat yang penting bagi pencapaian suatu standar, ukuran, serta kriteria yang telah ditetapkan dalam suatu pembelajaran. Khusus untuk kegiatan pembelajaran, kompetensi yang dijadikan dasar penilaian kinerja guru adalah: (1) kompetensi pedagogik; (2) kompetensi profesional; (3) kompetensi kepribadian; dan (4) kompetensi sosial. Kompetensi tersebut ditetapkan dalam Permendiknas Nomor 16 Tahun 2007 tentang Standar Kualifikasi Akademik dan Kompetensi Guru (Depdiknas, 2007). Keempat kompetensi ini telah dijabarkan menjadi kompetensi guru yang harus mewarnai perilaku guru dalam melaksanakan tugas dan fungsinya, terutama kompetensi pedagogik dan profesional yang berkaitan langsung dengan pembelajaran.

Permendikbud nomor 103 tahun 2014

Pasal 2, memberikan anjuran untuk menggunakan pembelajaran berbasis aktivitas. Pembelajaran aktif adalah proses belajar yang sangat baik digunakan dalam mengajar keterampilan proses. Strategi ini menyediakan sarana bagi peserta didik untuk belajar keterampilan dan lebih mudah mengenali dan melatih peserta didik ketika berpartisipasi dalam kegiatan yang lebih kompleks, yaitu kegiatan pembelajaran berbasis proyek (Monsenson, 2011). Pendekatan saintifik merupakan pendekatan yang sering dianjurkan dalam sebuah pembelajaran, karena pendekatan tersebut memberikan banyak manfaat bagi kemajuan pendidikan peserta didik, yaitu peserta didik mampu memiliki suatu pengalaman belajar.

Beberapa hal yang menjadi penyebab dari ketidaksiapan guru melangsungkan pembelajaran berbasis proses adalah kurangnya skill/kemampuan guru dalam melangsungkan pembelajaran berbasis proses. Guru juga beranggapan bahwa pembelajaran berbasis proses dianggap terlalu merepotkan, membebani dan tidak sesuai dengan tuntutan UN. Berdasarkan hasil tersebut, perlu dirumuskan pembelajaran yang mengedepankan pengalaman personal melalui pendekatan saintifik yang terdiri dari proses mengamati (observing), menanya (questioning), mencoba/mengumpulkan data (experimenting), menalar/mengasosiasis (associating), dan mengomunikasikan (communicating). Proses belajar seperti itu diharapkan dapat menghasilkan peserta didik yang produktif, kreatif, inovatif, dan afektif melalui penguatan sikap, pengetahuan, dan keterampilan yang terintegrasi.

PP Nomor 32 Tahun 2013 menyebutkan bahwa pengembangan pengetahuan dalam 
pembelajaran merupakan perwujudan suasana untuk meletakkan dasar kematangan proses berpikir dalam konteks belajar dan berinteraksi sosial. Bahan kajian yang termasuk dalam pengembangan pengetahuan adalah bahan kajian ilmu pengetahuan alam dan bahan kajian ilmu pengetahuan sosial, dan fisika merupakan salah satu mata pelajaran dalam bahan kajian ilmu pengetahuan alam yang digunakan dengan maksud untuk mengembangkan pengetahuan, pemahaman, dan kemampuan analisis peserta didik terhadap lingkungan alam dan sekitarnya.

Pengamatan lebih jauh tentang kompetensi guru saat ini agaknya masih beragam. Berdasarkan hasil pra survei yang dilakukan pada Oktober 2014 memberikan gambaran bahwa 8 dari 12 guru fisika lebih suka menggunakan pembelajaran ekspositori dan mengaku memiliki banyak kendala dalam melaksanakan pembelajaran berbasis proses. Terdapat indikasi tentang baik tidaknya kompetensi guru yang berhubungan dengan faktor luar, yaitu kepemimpinan kepala sekolah dan pelatihan guru. Penelitian ini akan mengungkap bagaimana korelasi kepemimpinan kepala sekolah dan pelatihan guru dengan kompetensi guru fisika, yaitu kompetensi pedagogik dan profesional guru.

Penelitian ini dilakukan di Kabupaten Sleman yang merupakan salah satu kabupaten di Daerah Istimewa Yogyakarta. Saat ini jumlah SMA di Kabupaten Sleman ada 51 sekolah yang tersebar di 17 kecamatan. SMA tersebut terdiri dari 17 SMA negeri dan 34 SMA swasta. Terdapat 7 SMA negeri yang termasuk ke dalam pilot project dalam menggunakan Kurikulum 2013. SMAN tersebut adalah SMAN 1 Godean, 1 Seyegan, 1 Sleman, 1 Pakem, 2 Ngaglik, 1 Kalasan, dan 1 Prambanan. SMAN tersebut telah memasuki tahun kedua dalam mengimpelemntasikan Kurikulum 2013, sehingga dengan kondisi seperti itu diharapkan dapat memberikan lebih banyak manfaat dalam penelitian ini.

Mengingat betapa pentingnya kompetensi pedagogik dan profesional guru serta manfaat pendekatan saintifik dalam sebuah pembelajaran, sehingga perlu untuk dilakukan penelitian tentang kompetensi pedagogik dan profesional guru fisika dalam melaksanakan pendekatan saintifik, untuk mengetahui seberapa baik kompetensinya dalam melaksanakan pendekatan saintifik, demikian pula dalam korelasinya dengan kepemimpinan kepala sekolah dan pelatihan yang diikuti oleh guru. Penelitian ini dilakukan terhadap guruguru fisika se-SMA Negeri di Kabupaten Sleman yang termasuk dalam pilot project dalam menerapkan kurikulum 2013.

\section{Metode Penelitian}

Jenis Penelitian

Penelitian ini merupakan penelitian kuantitatif, yaitu penelitian survei. Penelitian survei digunakan untuk mengetahui seberapa baik kompetensi pedagogik dan profesional dalam melaksanakan pendekatan saintifik guru fisika.

Tempat dan Waktu Penelitian

Penelitian ini dilaksanakan di SMA Negeri se-Kabupaten Sleman yang menggunakan kurikulum 2013 (pilot project) yang telah memasuki tahun kedua dalam mengimplementasikan kurikulum 2013 yang berjumlah tujuh sekolah yaitu: SMAN 1 Godean, 1 Seyegan, 1 Sleman, 1 Pakem, 2 Ngaglik, 1 Kalasan, dan 1 Prambanan. Waktu yang diperlukan untuk melaksanakan penelitian ini adalah kurang lebih tiga bulan pada semester genap tahun pelajaran 2014/2015.

Populasi dan Sampel Penelitian

Populasi dalam penelitian ini adalah guru fisika SMA Negeri di Kabupaten Sleman yang termasuk dalam pilot project yang menggunakan kurikulum 2013 sejak tahun pelajaran 2013/2014. Sampel dalam penelitian ini yaitu seluruh guru fisika yang mengajar kelas XI MIA di SMA Negeri di Kabupaten Sleman yang termasuk dalam pilot project yang telah mengimplementasikan kurikulum 2013 sejak tahun pelajaran 2013/2014.

Variabel Penelitian

Variabel dalam penelitian ini adalah: kompetensi pedagogik dan profesional guru fisika dalam melaksanakan pendekatan saintifik di SMA Negeri di Kabupaten Sleman.

Teknik Analisis Data

Teknik Pengumpulan Data

Pengumpulan data dalam penelitian ini dilakukan dengan menggunakan instrumen kuesioner (angket), observasi (pengamatan), interview (wawancara), dan dokumentasi. Instrumen ini dibuat berdasarkan tujuan penelitian untuk mengetahui seberapa baik kompetensi pedagogik dan profesional guru fisika dalam melaksanakan pendekatan saintifik di SMA Negeri di Kabupaten Sleman. Pada penelitian ini, instrumen divalidasi 
menggunakan validitas isi. Penentuan validitas dilakukan oleh 3 orang validator yang berasal dari 1 ahli dan 2 praktisi. Hasil dari validitas isi menunjukan bahwa semua butir soal dinyatakan valid.

Teknik Analisis Data

Analisis dilakukan dengan menggunakan analisis kuantitatif dengan pendekatan survei. Data yang diperoleh di lapangan akan diinterpretasikan ke setiap komponen yang diteliti, selanjutnya akan dideskripsikan penyebab-penyebabnya. Analisis kuantitatif dalam penelitian ini digunakan untuk menggambarkan data mengenai seberapa baik kompetensi pedagogik dan profesional guru fisika dalam melaksanakan pendekatan saintifik, kemudian data tersebut diinterpretasikan dalam kategori-kategori.

Analisis data selanjutnya menggunakan triangulasi data. Langkah-langkah triangulasi data yang dilakukan dalam penelitian ini adalah sebagai berikut.data reduksi, data display, conclussion.

Analisis data selanjutnya menggunakan uji korelasi. Uji korelasi yang digunakan dalam penelitian ini adalah uji korelasi Spearman dan uji korelasi koefisien kontingensi. Uji korelasi Spearman digunakan untuk mencari hubungan antara kepemimpinan kepala sekolah dengan kompetensi pedagogik dan profesional guru fisika. Uji korelasi koefisien kontingensi digunakan untuk mencari hubungan antara pelatihan guru dengan kompetensi pedagogik dan profesional guru fisika.

\section{Hasil Penelitian dan Pembahasan}

Analisis Kuantitatif

Kompetensi Pedagogik Guru Fisika

Kategori penilaian kompetensi pedagogik didasarkan pada pengkategorian yang disajikan pada Tabel 1, dan pengaktegorian setiap instrumen memberikan rentang yang berbedabeda.

Tabel 1. Pengkategorian Kompetensi Pedagogik Berdasarkan Jenis Instrumen

\begin{tabular}{cccc}
\hline Angket & Observasi & Wawancara & Kategori \\
\hline$X>85$ & $X>16$ & $X>17$ & Sangat Baik \\
\hline $70<X \leq 85$ & $12<X \leq 16$ & $14<X \leq 17$ & Baik \\
\hline $55<X \leq 70$ & $8<X \leq 12$ & $11<X \leq 14$ & Cukup \\
\hline $40<X \leq 55$ & $4<X \leq 8$ & $8<X \leq 11$ & Kurang \\
\hline$X \leq 40$ & $X \leq 4$ & $X \leq 8$ & Sangat Kurang \\
\hline
\end{tabular}

Tabel 1 menunjukkan pengkategorian penilaian kompetensi pedagogik guru dibagi dalam 5 kategori yang terdiri dari sangat baik, baik, cukup, kurang, dan sangat kurang. Pengkategorian menunjukkan hasil yang berbeda sesuai dengan jumlah indikator yang terdapat pada instrumen didik, observasi, dan wawancara yang disajikan dalam Tabel 2. dapat diperoleh skor yang dianalisis dari instrumen angket guru dan Skor tersebut akan di kelompokkan berdasarkan kategori-kategori untuk mengetahui seberapa baik kompetensi pedagogik dan profesional guru fisika dalam melaksanakan pendekatan saintifik.

Tabel 2. Skor Kompetensi Pedagogik Guru Fisika Berdasarkan Jenis Instrumen

\begin{tabular}{cccccc}
\hline \multirow{2}{*}{ No } & Kode & \multicolumn{5}{c}{ Jenis Instrumen } \\
\cline { 3 - 6 } & Guru & Angket Guru & Angket Pesdik & Observasi & Wawancara \\
\hline 1. & A1 & 92 & 74,90 & 15 & 18 \\
\hline 2. & B1 & 95 & 78,80 & 18 & 18 \\
\hline 3. & C1 & 74 & 69,00 & 14 & 16 \\
\hline 4. & C2 & 83 & 79,97 & 14 & 13 \\
\hline 5. & D1 & 86 & 80,41 & 19 & 19 \\
\hline 6. & D2 & 89 & 72,19 & 10 & 12 \\
\hline 7. & E1 & 95 & 84,19 & 18 & 19 \\
\hline 8. & F1 & 91 & 75,96 & 13 & 16 \\
\hline 9. & F2 & 91 & 73,40 & 19 & 19 \\
\hline 10. & F3 & 93 & 82,81 & 18 & 16 \\
\hline 11. & G1 & 82 & 75,15 & 13 & 15 \\
\hline 12. & G2 & 63 & 85,30 & 12 & 12 \\
\hline kompetensi pedagogik guru fisika & observasi, & dan & wawancara
\end{tabular}

yang diperoleh dari instrumen angket, diinterpretasikan kedalam kategori-kategori 
JPFK, Vol. 2 No. 2, September 2016, hal 92 -104

http://e-journal.ikippgrimadiun.ac.id/index.php/JPFK

untuk memperoleh kesimpulan yang disajikan dalam Tabel 3.

Tabel 3. Hasil Pengkategorian 3 Jenis Instrumen

\begin{tabular}{|c|c|c|c|c|c|c|}
\hline \multirow[b]{2}{*}{ No } & \multirow[b]{2}{*}{$\begin{array}{l}\text { Kode } \\
\text { Guru }\end{array}$} & \multicolumn{4}{|c|}{ Jenis Instrumen } & \multirow[b]{2}{*}{$\begin{array}{c}\text { Kesim } \\
\text { pulan }\end{array}$} \\
\hline & & $\begin{array}{c}\text { Angket } \\
\text { Guru }\end{array}$ & $\begin{array}{l}\text { Angket } \\
\text { Pesdik }\end{array}$ & $\begin{array}{l}\text { Obse } \\
\text { rvasi }\end{array}$ & $\begin{array}{l}\text { Wawa } \\
\text { ncara }\end{array}$ & \\
\hline 1. & A1 & SB & B & B & SB & B \\
\hline 2. & B1 & SB & B & SB & SB & SB \\
\hline 3. & $\mathrm{C} 1$ & B & C & B & B & B \\
\hline 4. & $\mathrm{C} 2$ & B & B & B & $\bar{C}$ & B \\
\hline 5. & D1 & SB & $\mathrm{B}$ & SB & SB & SB \\
\hline 6. & $\mathrm{D} 2$ & SB & $\mathrm{B}$ & $\mathrm{C}$ & $\mathrm{C}$ & $\mathrm{C}$ \\
\hline 7. & E1 & SB & $\mathrm{B}$ & SB & SB & SB \\
\hline 8. & F1 & SB & $\mathrm{B}$ & $\mathrm{B}$ & $\mathrm{B}$ & $\mathrm{B}$ \\
\hline 9. & F2 & SB & B & SB & SB & SB \\
\hline 10. & F3 & SB & B & SB & $\mathrm{B}$ & SB \\
\hline 11. & G1 & $\mathrm{B}$ & $\mathrm{B}$ & $\mathrm{B}$ & $\mathrm{B}$ & $\mathrm{B}$ \\
\hline 12. & G2 & $\mathrm{C}$ & SB & $\mathrm{C}$ & $\mathrm{C}$ & $\mathrm{C}$ \\
\hline
\end{tabular}

Berdasarkan Tabel 3 terdapat 5 guru dengan kategori baik, dan ada 2 guru dengan yang memiliki kompetensi pedagogik dengan kategori sangat baik, kemudian ada 5 guru kategori cukup.

Tabel 4. Persentase Pengkategorian Kompetensi Pedagogik Guru Fisika

\begin{tabular}{ccc}
\hline Kategori & Frekuensi & Persentase (\%) \\
\hline Sangat Baik (SB) & 5 & 42 \\
\hline Baik (B) & 5 & 42 \\
\hline Cukup (C) & 2 & 16 \\
\hline Kurang (K) & 0 & 0 \\
\hline Sangat Kurang (SK) & 0 & 0
\end{tabular}

Tabel 4 menunjukkan bahwa kompetensi memiliki persentase $42 \%$, dan kategori cukup pedagogik guru fisika dengan kategori sangat baik memiliki persentase $42 \%$, kategori baik memiliki persentase $16 \%$.

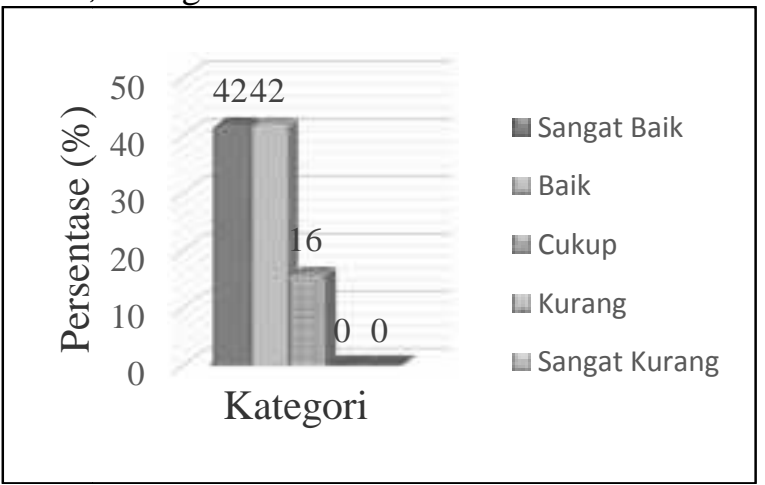

\section{Gambar 1. Histogram Persentase Kompetensi Pedagogik Guru Fisika Berdasarkan Triangulasi 3 Jenis Instrumen.}

Gambar 1 dapat memperlihatkan hasil dari persentase kompetensi pedagogik dalam melaksanakan pendekatan saintifik berdasarkan triangulasi 3 jenis instrumen yaitu instrumen angket, observasi, dan wawancara. Berdasarkan hasil dari analisis ketiga instrumen tersebut, dapat diambil kesimpulan bahwa kompetensi pedagogik guru fisika dalam melaksanakan pendekatan saintifik secara keseluruhan dikategorikan baik.

Terdapat beberapa guru yang memiliki hasil yang berbeda antara instrumen angket, observasi, dan wawancara. Perbedaan tersebut disebabkan beberapa hal yang berkaitan dengan indikator berikut:

Mengenal karakteristik peserta didik

Guru memilih pernyataan bahwa telah melakukan identifikasi karakteristik peserta didik setiap melakukan proses pembelajaran. Hasil observasi memberikan jawaban yang berbeda, bahwa guru melakukan identifikasi karakteristik peserta didik hanya ketika ada keperluan tertentu saja, hal ini juga dikuatkan 
dengan wawancara yang dilakukan terhadap peserta didik.

Guru memilih pernyataan mengidentifikasi potensi peserta didik kemudian mengembangkannya, dan mengidentifikasi kekurangan peserta didik kemudian memotivasinya. Hasil observasi memperlihatkan bahwa guru hanya memberikan kesempatan kepada peserta didik yang berminat mengembangkan potensinya tanpa harus melalui tahap mengidentifikasi potensi peserta didik, sedangkan hasil wawancara memberikan informasi bahwa guru baru akan mencari peserta didik yang berpotensi ketika akan diikutkan dalam suatu perlombaan.

Menguasai teori belajar dan prinsip-prinsip pembelajaran yang mendidik berbasis pendekatan saintifik

Guru menyatakan bahwa memberikan materi pembelajaran sesuai dengan kemampuan peserta didik melalui sebuah pengamatan. Hasil observasi dan wawancara dengan peserta didik memberikan hasil yang berbeda bahwa guru lebih sering memberikan materi pelajaran kepada peserta didik untuk dipelajari sendiri, misalnya dengan menyuruh peserta didik untuk mengerjakan LKS tanpa adanya pengenalan materi terlebih dahulu.

Guru memilih pernyataan bahwa setiap melakukan pembelajaran guru memotivasi dan mengembangkan karakter belajar peserta didik. Hasil yang berbeda ditunjukkan oleh jawaban peserta didik bahwa peserta didik dapat memotivasi dan mengembangkan karakter belajar tanpa bantuan guru. Setelah dilakukan observasi, diperoleh informasi bahwa peserta didik sudah mengikuti bimbingan belajar secara mandiri di rumah, sehingga merasa motivasi yang diberikan oleh guru tidak terlalu memberikan banyak pengaruh.

Mengembangkan kurikulum

Guru memilih pernyataan bahwa guru merasa tertantang untuk merancang rencana pembelajara. Hasil yang berbeda diperoleh dari observasi, yaitu guru menggunakan RPP yang telah dirancang dalam forum MGMP atau menggunakan RPP dari teman sejawat untuk digunakan dalam pembelajarannya.
Melakukan kegiaan pembelajaran yang mendidik

Guru menyatakan bahwa guru menggunakan pendekatan saintifik dalam perencanaan, pelaksanaan, dan penilaian pembelajaran. Hasil yang berbeda diberikan oleh kegiatan observasi, yaitu guru lebih cenderung menggunakan kegiatan pembelajaran ekspositori.

Guru memilih pernyataan bahwa guru memilih strategi pembelajaran yang cocok sehingga tercipta pembelajaran yang menyenangkan. Hasil yang berbeda diberikan dari kegiatan observasi, yaitu suasana yang diciptakan oleh guru dalam kegiatan pembelajaran membuat peserta didik tidak bersemangat untuk mengikuti pembelajaran.

Mengembangkan potensi peserta didik

Guru memilih pernyataan bahwa guru mengidentifikasi bakat, minat, dan potensi masing-masing peserta didik dan mengembangkannya secara optimal. Hasil yang berbeda diberikan oleh data observasi, yaitu guru tidak melakukan identifikasi bakat, minat, dan potensi masing-masing peserta didik karena hal itu dianggap terlalu sulit untuk dikerjakan.

Melakukan komunikasi dengan peserta didik

Komunikasi yang dilakukan oleh semua guru terjalin baik dengan peserta didik. Guru memberikan perhatian serta mendengarkan pertanyaan yang diajukan oleh peseta didik. Guru menggunakan pertanyaan terbuka untuk berkomunikasi dengan peserta didik sehingga membuat peserta didik merasa bersemangat.

Melakukan penilaian dan evakuasi

Guru memilih pernyataan bahwa guru membuat dan melaksanakan penilaian dengan berbagai teknik dan jenis penilaian selain penilaian formal. Hasil yang berbeda diberikan oleh hasil observasi, yaitu guru menggunakan penilaian yang hanya didasarkan pada aspek pengetahuan saja.

Kompetensi Profesional Guru Fisika

Kategori penilaian kompetensi profesional didasarkan pada pengkategorian yang disajikan pada Tabel 5, dan pengaktegorian setiap instrumen memberikan rentang yang berbeda-beda.

Tabel 5. Pengkategorian Kompetensi Profesional Berdasarkan Jenis Instrumen

\begin{tabular}{cccc}
\hline Angket & Observasi & Wawancara & Kategori \\
\hline
\end{tabular}


JPFK, Vol. 2 No. 2, September 2016, hal 92 -104

http://e-journal.ikippgrimadiun.ac.id/index.php/JPFK

\begin{tabular}{cccc}
\hline$X>34$ & $X>24$ & $X>17$ & Sangat Baik \\
\hline $28<X \leq 34$ & $18<X \leq 24$ & $14<X \leq 17$ & Baik \\
\hline $22<X \leq 28$ & $12<X \leq 18$ & $11<X \leq 14$ & Cukup \\
\hline $16<X \leq 22$ & $6<X \leq 12$ & $8<X \leq 11$ & Kurang \\
\hline$X \leq 16$ & $X \leq 6$ & $X \leq 8$ & Sangat Kurang \\
\hline
\end{tabular}

Kategori penilaian kompetensi profesional didasarkan pada komponenobservasi, dan wawancara yang masing-masing komponen yang terdiri dari instrumen angket, menunjukkan kategori yang berbeda.

Tabel 6. Skor Kompetensi Profesional Guru Fisika Berdasrkan Jenis Instrumen

\begin{tabular}{cccccc}
\hline \multirow{2}{*}{ No } & Kode & Guru & Angket Guru & \multicolumn{2}{c}{ Jenis Instrumen } \\
\cline { 3 - 6 } & Angket Pesdik & Observasi & Wawancara \\
\hline 1. & A1 & 39 & 33,66 & 20 & 19 \\
\hline 2. & B1 & 35 & 34,70 & 29 & 16 \\
\hline 3. & C1 & 35 & 31,03 & 27 & 17 \\
\hline 4. & C2 & 31 & 36,19 & 20 & 16 \\
\hline 5. & D1 & 34 & 33,19 & 28 & 18 \\
\hline 6. & D2 & 36 & 36,26 & 18 & 16 \\
\hline 7. & E1 & 35 & 33,84 & 29 & 16 \\
\hline 8. & F1 & 36 & 34,48 & 19 & 17 \\
\hline 9. & F2 & 33 & 35,77 & 19 & 16 \\
\hline 10. & F3 & 40 & 35,77 & 28 & 20 \\
\hline 11. & G1 & 37 & 34,10 & 19 & 18 \\
\hline 12. & G2 & 29 & 37,30 & 17 & 13 \\
\hline
\end{tabular}

Skor kompetensi profesional guru fisika yang diperoleh dari instrumen angket, observasi, dan wawancara kemudian

diinterpretasikan kedalam kategori-kategori untuk memperoleh kesimpulan yang disajikan dalam Tabel 7.

Tabel 7. Hasil Pengkategorian 3 Jenia Instrumen

\begin{tabular}{|c|c|c|c|c|c|c|}
\hline \multirow[b]{2}{*}{ No } & \multirow{2}{*}{$\begin{array}{l}\text { Kode } \\
\text { Guru }\end{array}$} & \multicolumn{4}{|c|}{ Jenis Instrumen } & \multirow{2}{*}{$\begin{array}{c}\text { Kesim } \\
\text { pulan }\end{array}$} \\
\hline & & $\begin{array}{c}\text { Angket } \\
\text { Guru }\end{array}$ & $\begin{array}{l}\text { Angket } \\
\text { Pesdik }\end{array}$ & $\begin{array}{c}\text { Observ } \\
\text { asi }\end{array}$ & $\begin{array}{c}\text { Wawan } \\
\text { cara }\end{array}$ & \\
\hline 1. & A1 & SB & B & $B$ & SB & $B$ \\
\hline 2. & B1 & SB & SB & SB & B & SB \\
\hline 3. & $\mathrm{C} 1$ & SB & B & SB & B & B \\
\hline 4. & $\mathrm{C} 2$ & B & SB & B & B & B \\
\hline 5. & D1 & B & B & SB & SB & SB \\
\hline 6. & D2 & SB & SB & $\mathrm{C}$ & B & B \\
\hline 7. & E1 & SB & B & SB & B & SB \\
\hline 8. & $\mathrm{~F} 1$ & SB & SB & B & B & B \\
\hline 9. & $\mathrm{~F} 2$ & B & SB & B & B & Baik \\
\hline 10. & F3 & SB & SB & SB & SB & SB \\
\hline 11. & G1 & SB & SB & B & SB & SB \\
\hline 12. & $\mathrm{G} 2$ & B & SB & $\mathrm{C}$ & $\mathrm{C}$ & $\mathrm{C}$ \\
\hline
\end{tabular}

Berdasarkan Tabel 7 terdapat 5 guru yang memiliki kompetensi profesional dengan dengan kategori baik, dan ada 1 guru dengan kategori cukup.

kategori sangat baik, kemudian ada 6 guru

Tabel 8. Persentase Pengkategorian Kompetensi Profesional Guru Fisika

\begin{tabular}{ccc}
\hline Kategori & Frekuensi & Persentase (\%) \\
\hline Sangat Baik (SB) & 5 & 42 \\
\hline Baik (B) & 6 & 50 \\
\hline Cukup (C) & 1 & 8 \\
\hline Kurang (K) & 0 & 0 \\
\hline Sangat Kurang (SK) & 0 & 0 \\
\hline
\end{tabular}


Tabel 8 menunjukkan bahwa kompetensi profesional guru fisika dengan kategori sangat baik memiliki persentase $42 \%$, kategori baik memiliki persentase $50 \%$, dan kategori cukup memiliki persentase $8 \%$.

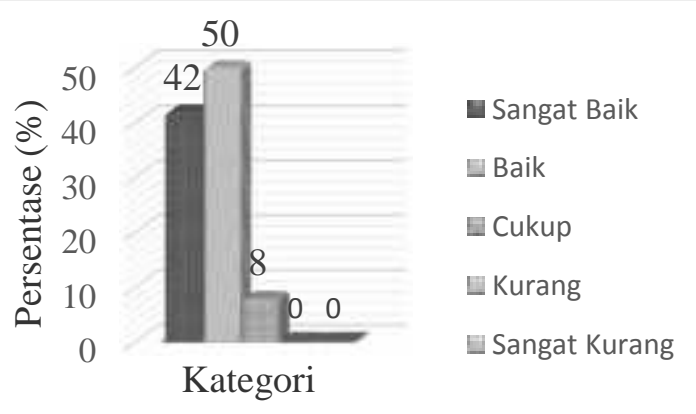

\section{Gambar 2. Histogram Persentase Kompetensi Profesional Guru Fisika Berdasarkan Triangulasi 3 Jenis Instrumen}

Gambar 2 memperlihatkan hasil dari persentase kompetensi profesional dalam melaksanakan pendekatan saintifik berdasarkan triangulasi 3 jenis instrumen yaitu instrumen angket, observasi, dan wawancara. Berdasarkan hasil dari analisis ketiga instrumen tersebut, dapat diambil kesimpulan bahwa kompetensi profesional guru fisika dalam melaksanakan pendekatan saintifik secara keseluruhan dikategorikan baik.

Terdapat beberapa guru yang memiliki hasil yang berbeda antara instrumen angket, observasi, dan wawancara. Perbedaan tersebut disebabkan beberapa hal yang berkaitan dengan indikator berikut:

Menguasai materi, struktur, konsep, dan pola pikir keilmuan yang mendukung mata pelajaran

Guru memilih pernyataan bahwa guru mencari informasi di internet agar dapat menguasai materi pelajaran sepenuhnya. Hasil observasi memberikan jawaban yang berbeda, yaitu guru tidak menggunakan internet untuk menguasai materi pelajaran. Bahkan, guru tidak bisa memanfaatkan internet sebagai salah satu sumber informasi.

Guru memilih pernyataan bahwa guru selalu menyertakan informasi penting dalam perencanaan dan pelaksanaan pembelajaran di kelas. Hasil observasi memberikan jawaban yang berbeda, guru mengajar tidak menggunakan perencanaan sebelumnya dan tidak menyertakan informasi penting saat pelaksanaan pembelajaran.

Menguasai KI dan KD mata pelajaran yang diampu

Guru memilih pernyataan bahwa guru melakukan pemetaan kompetensi inti dan kompetensi dasar untuk materi pelajaran yang diangap sulit, melakukan perencanaan dan pelaksanaan pembelajaran, dan memperkirakan alokasi waktu. Hasil observasi menunjukkan hasil yang berbeda, guru tidak membuat perencanaan pembelajaran, dan tidak memperkirakan alokasi waktu yang diperlukan. Perencanaan atau RPP yang digunakan oleh guru adalah RPP dari tahun sebelumnya yang informasinya belum diperbarui kembali.

Mengembangkan materi pembelajaran secara kreatif menggunakan pendekatan saintifik

Keinginan guru untuk mengembangkan materi pembelajaran secara kreatif menggunakan pendekatan saintifik masih mendapatkan beberapa kendala, salah satunya karena tuntutan Ujian Nasional yang mengharuskan peserta didik mampu menguasai materi pembelajaran, sehingga guru merasa nyaman dengan pembelajaran ekspositori dimana guru sebagai pusat pembelajaran.

Mengembangkan keprofesionalan melalui tindakan yang reflektif

Guru memilih pernyataan bahwa guru mengisi jurnal pembelajaran dan mencatat semua masukan dari kolega. Observasi menunjukkan hasil yang berbeda, guru memiliki jurnal pembelaaran yang diberikan oleh sekolah, tetapi tidak diisi untuk kepentingan mengembangkan keprofesionalan. Memanfaatkan TIK untuk komunikasi dan pengembangan diri

Guru memilih pernyataan bahwa guru merasa bersemangat memanfaatkan TIK untuk membuat tugas-tugas. Observasi dan wawancara memberikan hasil yang berbeda, guru tidak terbiasa menggunakan TIK (laptop) 
dalam mengerjakan tugas yang berkaitan dengan pembelajaran sehari-hari. Guru memanfaatkan laptop hanya ketika ada tugas dari sekolah yang sifatnya kelembagaan.

\section{Uji Korelasi}

Korelasi Antara Kepemimpinan Kepala Sekolah dengan Kompetensi Pedagogik dan Profesional Guru Fisika
Uji korelasi Spearman digunakan untuk mengetahui ada tidaknya korelasi antara kepemimpinan kepala sekolah $\left(\mathrm{Y}_{1}\right)$ dengan kompetensi pedagogik dalam melaksanakan pendekatan saintifik guru fisika $\left(\mathrm{X}_{1}\right)$, dan korelasi antara kepemimpinan kepala sekolah $\left(\mathrm{Y}_{1}\right)$ dengan kompetensi profesional dalam melaksanakan pendekatan saintifik guru fisika $\left(\mathrm{X}_{2}\right)$.

Tabel 9. Hasil Uji Korelasi Spearman antara Kepemimpinan Kepala Sekolah dan Kompetensi Pedagogik Guru Fisika

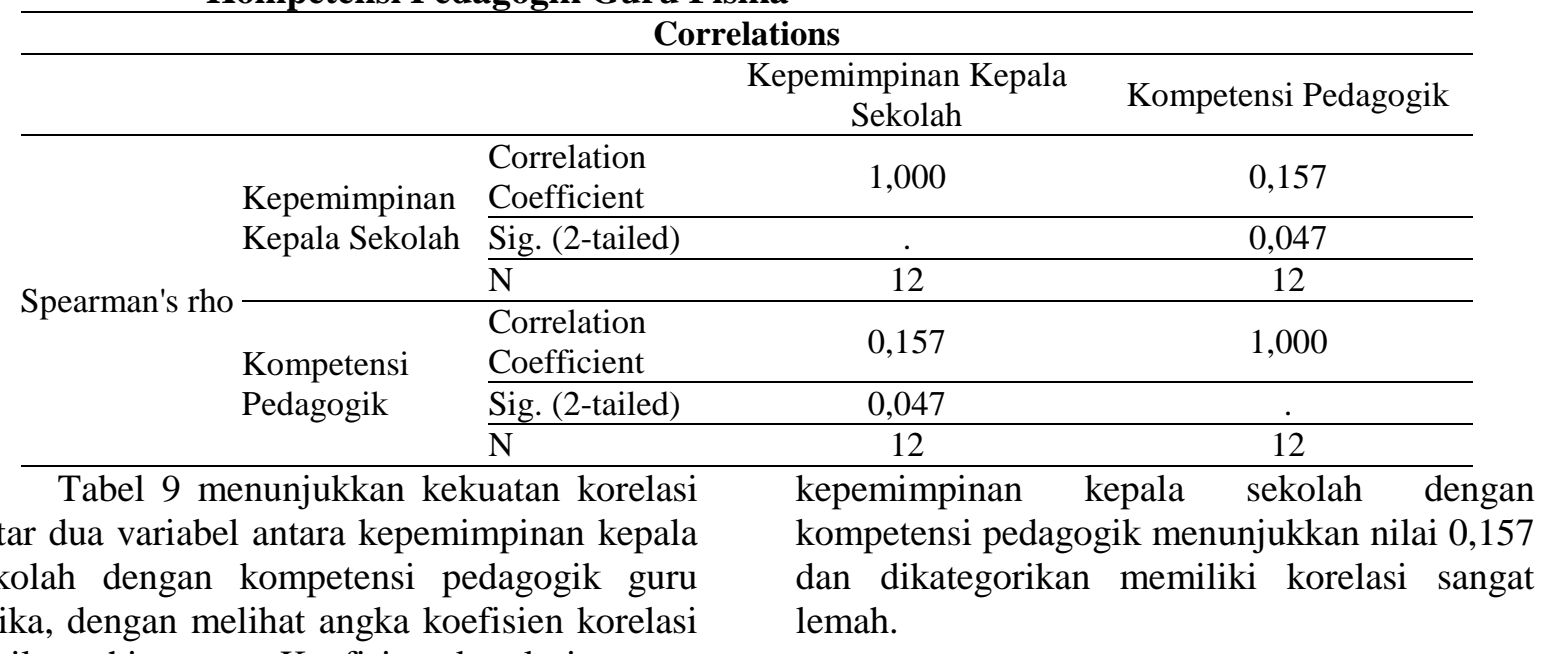

hasil perhitungan. Koefisien korelasi antara

Tabel 10. Hasil Uji Korelasi Spearman antara Kepemimpinan Kepala Sekolah dan Kompetensi Profesional Guru Fisika

\begin{tabular}{|c|c|c|c|c|}
\hline \multicolumn{5}{|c|}{ Correlations } \\
\hline & & & $\begin{array}{l}\text { Kepemimpinan Kepala } \\
\text { Sekolah }\end{array}$ & Kompetensi Profesional \\
\hline \multirow{6}{*}{ Spearman's rho } & \multirow{3}{*}{$\begin{array}{l}\text { Kepemimpinan } \\
\text { Kepala Sekolah }\end{array}$} & Correlation & 1,000 & 0,535 \\
\hline & & Sig. (2-tailed) &. & 0,043 \\
\hline & & $\mathrm{N}$ & 12 & 12 \\
\hline & \multirow{3}{*}{$\begin{array}{l}\text { Kompetensi } \\
\text { Profesional }\end{array}$} & $\begin{array}{l}\text { Correlation } \\
\text { Coefficient }\end{array}$ & 0,535 & 1,000 \\
\hline & & Sig. (2-tailed) & 0,043 & . \\
\hline & & $\mathrm{N}$ & 12 & 12 \\
\hline
\end{tabular}

Tabel 10 menunjukkan kekuatan korelasi antar dua variabel antara kepemimpinan kepala sekolah dengan kompetensi profesional guru fisika, dengan melihat angka koefisien korelasi hasil perhitungan. Koefisien korelasi antara kepemimpinan kepala sekolah dengan kompetensi profesional menunjukkan nilai 0,535 dan dikategorikan memiliki korelasi kuat.

Penyebab lemahnya korelasi antara kepemimpinan kepala sekolah dengan kompetensi pedagogik berkaitan dengan indikator kepemimpinan kepala sekolah berikut:

Kepala sekolah sebagai pemimpin
Tugas kepala sekolah untuk menyusun perencanaan sekolah sering kali melibatkan guru. Tugas tersebut antara lain: melibatkan guru untuk ikut merumuskan perencanaan jangka panjang, menengah, dan tahunan; demikian pula ketika merumuskan tujuantujuan sekolah. Tugas kepala sekolah dalam mengelola kelembagaan sekolah yang sering melibatkan guru antara lain: mengorganisasikan guru dalam merumuskan dan membagi tugas sekolah; selain itu kepala sekolah juga sering mengoordinasi guru dalam menentukan mekanisme program sekolah. Tugas kepala sekolah untuk menerapkan kepemimpinan dalam pekerjaan dilakukan untuk menjaga 
kualitas guru dalam lembaga, dilakukan dengan mendayakan kemampuan guru secara maksimal; memberikan motivasi kerja kepada guru, menegakkan disiplin kerja guru; mengawasi pekerjaan guru, melakukan supervisi proses pembelajaran; menindaklajuti supervisi tersebut, dan mengevaluasi.

Beberapa tugas yang diberikan oleh kepala sekolah sebagai pemimpin kepada guru tersebut merupakan tugas kelembagaan yang tidak berkaitan dengan kompetensi pedagogik guru fisika dalam melaksanakan pembelajaran di kelas. Guru tetap mengajar atau mencari pertemuan pengganti seandainya guru diminta kepala sekolah untuk melaksanakan tugas penting. Tugas kepala sekolah yang memiliki korelasi terhadap kompetensi pedagogik guru adalah kegiatan supervisi proses pembelajaran. Kegiatan supervisi proses pembelajaran akan meningkatkan kompetensi pedagogik guru.

Kepala sekolah sebagai manager

Tugas kepala sekolah untuk mengelola tenaga kependidikan yang sering melibatkan guru antara lain: menggunakan partisipasi guru untuk melancarkan komunikasi di sekolah; menciptakan komunikasi dua arah dengan guru; menghargai keterlibatan guru dalam menyusun program-program kegiatan sekolah. Tugas kepala sekolah dalam mengelola sarana dan prasarana yang sering melibatkan guru antara lain: menginformasikan kepada guru tentang apa yang harus dikerjakan; memberikan mandat kepada guru untuk melaksanakan pembelajaran dengan baik, lancar, dan produktif. Tugas kepala sekolah dalam mengelola hubungan dengan masyarakat yang sering melibatkan guru antara lain: berupaya mengembangkan suasana yang bersahabat; menaruh kepercayaan kepada guru; mendukung pengembangan profesi yang dilakukan guru seperti membuat karya ilmiah, artikel, dll.

Uji Korelasi antara Pelatihan Guru dan Kompetensi Pedagogik Guru Fisika

Uji Korelasi Koefisien Kontingensi digunakan untuk mencari korelasi antara pelatihan guru $\left(\mathrm{Y}_{2}\right)$ dengan kompetensi pedagogik dalam melaksanakan pendekatan saintifik guru fisika $\left(\mathrm{X}_{1}\right)$, dan korelasi antara pelatihan guru $\left(\mathrm{Y}_{2}\right)$ dengan kompetensi profesional dalam melaksanakan pendekatan saintifik guru fisika $\left(\mathrm{X}_{2}\right)$. Uji korelasi koefisien kontingensi pada penelitian ini menggunakan perhitungan Chi-square dengan program SPSS versi 21.

Tabel 11. Hasil Uji Korelasi Koefisien Kontingensi antara Pelatihan Guru dan Kompetensi Profesional Guru Fisika

\begin{tabular}{lccc}
\hline \multicolumn{4}{c}{ Chi-Square Tests } \\
\hline & Value & df & Asymp. Sig.(2-sided) \\
\hline Pearson Chi-Square & $2,400^{\mathrm{a}}$ & 2 & 0,301 \\
\hline Likelihood Ratio & 3,175 & 2 & 0,204 \\
\hline Linear-by-Linear Association & 0,129 & 1 & 0,719 \\
\hline N of Valid Cases & 12 & \\
\hline a. 5 cells $(83,3 \%)$ have expected count less than 5. The minimum expected count is $0,33$. \\
\hline
\end{tabular}

Tabel 11 menunjukkan pada bagian Pearson Chi-Square terlihat nilai Asymp. Sig sebesar 0,301. Nilai Asymp. Sig. 0,301 > 0,05, maka dapat disimpulkan bahwa Ho diterima, yang artinya tidak ada korelasi yang signifikan antara pelatihan guru dengan kompetensi pedagogik dalam melaksanakan pendekatan saintifik guru fisika.

Penyebab kuatnyanya korelasi antara kepemimpinan kepala sekolah dengan kompetensi profesional berkaitan dengan indikator kepemimpinan kepala sekolah berikut:

\section{Kepala sekolah sebagai pemimpin}

Tugas kepala sekolah untuk menerapkan kepemimpinan dalam pekerjaan dilakukan untuk menjaga kualitas guru dalam lembaga, dilakukan dengan mendayakan kemampuan guru secara maksimal; memberikan motivasi kerja kepada guru, menegakkan disiplin kerja guru; mengawasi pekerjaan guru, melakukan supervisi proses pembelajaran; menindaklajuti supervisi tersebut, dan mengevaluasi.

Beberapa tugas yang diberikan oleh kepala sekolah sebagai pemimpin kepada guru tersebut memiliki korelasi yang kuat terhadap kompetensi profesional dalam melaksanakan pendekatan saintifik guru fisika. Tugas tersebut mampu membuat guru untuk meningkatkan pengetahuannya dalam mengelola pembelajaran secara maksimal. Guru merasa mendapatkan perhatian melalui suatu pengawasan, supervisi, dan evaluasi sehingga guru lebih termotivasi meningkatkan pengetahuan agar memiliki prestasi yang baik ketika mengikuti tes kompetensi guru. 
Kepala sekolah sebagai manager

Tugas kepala sekolah dalam mengelola korelasi dengan masyarakat yang sering melibatkan guru antara lain: mendukung pengembangan profesi yang dilakukan guru seperti membuat karya ilmiah, artikel, dll. Tugas kepala sekolah yang sering melibatkan guru, tersebut merupakan tugas yang dapat meningkatkan kompetensi profesional guru. Kepala sekolah mendukung sepenuhnya guru yang ingin meningkatkan kemampuannya tidak hanya dengan pembuatan sebuah karya tetapi juga mengikuti berbagai pelatihan yang penting bagi peningkatan kompetensi.

Tabel 12. Hasil Uji Korelasi Koefisien Kontingensi antara Pelatihan Guru dan Kompetensi Profesional Guru Fisika

\begin{tabular}{lccc}
\hline \multicolumn{4}{c}{ Chi-Square Tests } \\
\hline & Value & df & Asymp. Sig.(2-sided) \\
\hline Pearson Chi-Square & $1,091^{\mathrm{a}}$ & 2 & 0,580 \\
\hline Likelihood Ratio & 1,477 & 2 & 0,478 \\
\hline Linear-by-Linear Association & 0,059 & 1 & 0,808 \\
\hline N of Valid Cases & 12 & \\
\hline a. 5 cells (83,3\%) have expected count less than 5. The minimum expected count is 0,33.
\end{tabular}

Tabel 12 pada bagian Pearson ChiSquare terlihat nilai Asymp. Sig sebesar 0,580. Nilai Asymp. Sig. 0,580 > 0,05, maka dapat disimpulkan bahwa Ho diterima, yang artinya tidak ada korelasi yang signifikan antara pelatihan guru dengan kompetensi profesional dalam melaksanakan pendekatan saintifik guru fisika

\section{Simpulan}

Simpulan

Kompetensi pedagogik guru fisika dalam melaksanakan pendekatan saintifik secara keseluruhan dikategorikan baik berdasarkan hasil yang diperoleh dari triangulasi data dari instrumen angket, observasi, dan wawancara. Kompetensi profesional guru fisika dalam melaksanakan pendekatan saintifik secara keseluruhan dikategorikan baik berdasarkan hasil yang diperoleh dari triangulasi data dari instrumen angket, observasi, dan wawancara. Koefisien korelasi antara kepemimpinan kepala sekolah dengan kompetensi pedagogik dalam melaksanakan pendekatan saintifik guru fisika dikategorikan memiliki korelasi sangat lemah. Koefisien korelasi antara kepemimpinan kepala sekolah dengan kompetensi profesional dalam melaksanakan pendekatan saintifik guru fisika dikategorikan memiliki korelasi kuat. Tidak ada korelasi yang signifikan antara pelatihan yang diikuti guru dengan kompetensi pedagogik guru fisika dalam melaksanakan pendekatan saintifik. Tidak ada korelasi yang signifikan antara pelatihan yang diikuti guru dengan kompetensi profesional guru fisika dalam melaksanakan pendekatan saintifik guru fisika.

\section{Daftar Pustaka}

Akinoglu, O. (2008). Assessment of the inquiry-based project implementation process in science education upon student's points of view. International Journal of Instruction, Vol. 1, No. 1.

Balistreri, S. (2012). Trends. The College Board.

Dwiyani, A. (2012). Keefektifan kinerja guru sains dalam mengimplementasikan ktsp di smp/mts negeri se-kecamatan sumbawa, kabupaten sumbawa. Tesis magister, tidak diterbitkan, Universitas Negeri Yogyakarta, Yogyakarta.

Etherington, M. (2011). Investigative primary science: a problem-based learning approach. Australian Journal of Teacher Education, Vol. 9, Issue. 9.

Hartono. (2011). Statistik untuk penelitian. Pekanbaru: Pustaka Belajar.

Hasanah, D. S. (2010). Pengaruh pendidikan latihan (diklat) kepemimpinan guru dan iklim kerja terhadap kinerja guru sekolah dasar se kecamatan babakancikao kabupaten purwakarta. Jurnal Penelitian Pendidikan, 85-96, Vol. 11, No. 2.

Hilliyani. (2012). Pengaruh peran mgmp dan kepemimpinan kepala sekolah menurut persepsi guru terhadap 
kompetensi guru matematika smp/mts di kabupaten aceh tengah. Tesis Magister, tidak diterbitkan, Universitas Negeri Yogyakarta, Yogyakarta.

Hosnan, M. (2014). Pendekatan saintifik dan kontekstual dalam pembelajaran abad 21. Jakarta: Penerbit Ghalia Indonesia.

Hussain, A., Azeem, M., Shakoor, A. (2011). Physics teaching methods: scientific inquiry vs traditional lecture. International Journal of Humanities and Social Science, 273, Vol. 1, No. 19.

Irina, A., \& Liliana. (2011). Pedagogical competence - the key to efficient education. International Journal of Educational Sciences, 3(2), 411423.

Jumadi, Prasetyo, Z. K., \& Wilujeng, I. (May 2014). Mapping Of Professional, Pedagogical, Social, And Personal Competence Of Senior High School Physics Teachers In Yogyakarta Specila Region. International Conference On Research, Implementation, And Education Of Mathrmatics And Science (pp. 65-76). Yogyakarta: Yogyakarta State University.

Lawson, A. E. (2010). Teaching inquiry science in middle and secondary school. California: Sage Publication Inc.

Liakopoulou, M. (2011). The professional competence of teachers: which qualities, attitudes, skills, and kbowledge contribute to a teacher's efectiveness? International Journal Of Humanities And Social Science, Vol. 1, No. 21, 68-69.

Manan, M. B. (2014). Leadership characteristics of excelent headmasters. Journal of Education and Practice, Vo. 5, No. 23, 120123.

Monsenson, A. B., \& Fox, W. S. (2011). Teaching 21 st century process skills to strengthen and enhance family and consumer science education. Journal of Family and Consumer Science, Vol. 103, No. 1, 63-69.

Mulyasa, H. E. (2009). Standar kompetensi dan sertifikasi guru. Bandung: Rosda Karya.

(2013). Uji kompetensi dan penilaian kinerja guru. Bandung: Rosda Karya.

Mundilarto. (2012). Penilaian hasil belajar fisika. Yogyakarta: UNY Press.

Mutohar, P. M. (2013). Manajemen Mutu Sekolah. Yogyakarta: Ar-Ruzz Media.

Olatunji, M. O. (2013). Ensuring and promoting the pedagogical competence of university lectures in africa. Journal of Educational and Instructional Studies in The World, Vol. 3, Issue 3, Article 12, 75-76.

Parkay, F. W., \& Standford, B. H. (2011). Menjadi Seorang Guru. (Terjemahan Wasi Dewanto). New York: Pearson Education Inc. (Buku asli diterbitkan tahun 2010).

Payong, M. R. (2011). Sertifikasi profesi guru: konsep dasar, problematika, dan implementasinya. Jakarta: PT Indeks.

Ponnusamy, S., Rasarasan, S., Ramanujam, G., et al. (2007). Physics higher secondary first year volume - $i$. Chennai: Tamilnadu Textbook Corporation.

Priatna, N., \& Sukamto, T. (2013). Pengembangan profesi guru. Bandung: PT Remaja Rosda Karya.

Rice, U. (2013). College Physics. Texas: Openstax College.

Rochintaniawati, D. (2014). Pembelajaran ipa dengan menggunakan pendekatan saintifik dalam kurikulum 2013. Seminar Nasional Pendidikan MIPA (pp. 1-7). Padang: Universitas Negeri Padang.

Sagala, S. (2009). Kemampuan profesional guru dan tenaga kependidikan. Bandung: Alfabeta. 
Suriasumantri, J. S. (2009). Filsafat ilmu sebuah pengantar populer. Jakarta: Pustaka Sinar Harapan.

Tiantong, M., \& Tongchin, P. (2013). A multiple intelligences supported web-based collaboration learning model using stufflebeam's cipp evaluation model. International Journal of Humanities and Social Science, Vol. 3, No. 7, 157-165.

Wahjosumidjo. (2008). Kepemimpina kepala sekolah tujuan teoritik dan permasalahannya. Jakarta: PT Raja Grafindo Persada.

Waluya, B. (2010). Peningkatan Kualitas Sumber Daya Manusia Berbasis Masyarakat untuk Mengatasi Masalah Pengangguran. Bandung: Universitas Pendidikan Indonesia.
Wellington, J., \& Ireson, G. (2012). Science learning, science teaching third edition. Great Britain: TJ International.

Widoyoko, E. P. (2009). Evaluasi program pembelajaran. Yogyakarta: Pustaka Pelajar.

Widyaningsih, E. (2011). Evaluasi kinerja guru ipa smp se-provinsi daerah istimewa yogyakarta. Tesis magister, tidak diterbitkan, Universitas Negeri Yogyakarta, Yogyakarta.

William, J. D. (2012). How science works teaching and learning in the science classroom. India: Newgen Imaging System Pvt Ltd. 